\title{
Policy Research
}

Working PAPER 1215

\section{How Much Do Distortions Affect Growth?}

William Easterly

Contrary to the traditional view that distortions of relative prices have modest effects, Easterly finds that distortions can greatly affect growth and welfare.

The World Bank

Policy Research Department

Macroeconomics and Growth Division

November 1993 
Policy Resharch Working Paphe 1215

\section{Summary findings}

Easterly presents a simple endogenous growth model (with two types of capital) that shows the sizable long. run effects on growth of distortionary policies. The model applies to many different rypes of distortions of relative prices sommon in developing countries - - for exanp!e, price controls, black market exchange rates, and differential taxes and rariffs.

The model shows that distortions of relative input prices can grearly affect growth and weltare. The magnitude of the effect depends on the production elasticity of substitution. With high .ubstitutability, the effects on growth and welfare, although possibly large, are bounded, no matter how high the rate of distortion.

Subsidizing inputs and invesement goods can increase growth. even though it worsens weltare. But a

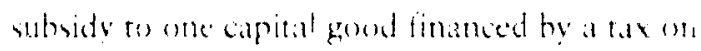
another capital good unambiguously reduces growth.

Empirical results show strong negative effects trom variance in the relative prices of investment goods acress secoors, while also confirming and extending earlier results showing that penalizing investment goods and distorting financial markets reduce growth.

This paper - a product of the Macroeconomics and Growth Division, Policy Research Department-- is pait of a larger effort in the department to relate long-run growth to national policies. The study was funded by the Bunk's Research Support Budget under the research project "How Do National Policies Atfect Long-Kun (irowth?" (RPO 676-66).

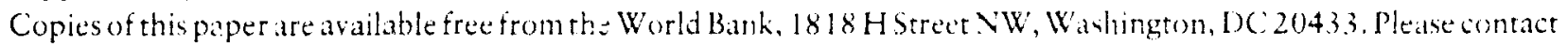
Rebecca Martin, room N11-0.35, extension 39065 (30 prages). Nuvember 1943.

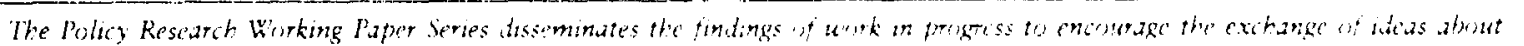

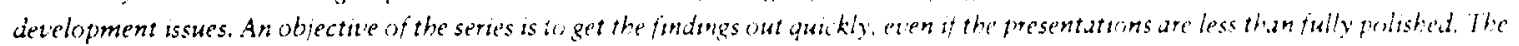
papers carry the names of the authors and should be used and cated accordingly. Thi findings interpretatuns. and conclustims are the authors' own and should not be attributed to the World Bank. its Executise Board of I verectors. or any of ts membet countries. 
forthcoming, Jouma of Menerary Ecenomics

\section{HOW MUCH DO DISTORTIONS AFFECT GROWTH?"}

\section{William Easterly}

World Bank. Washington DC 20433

correspondence to: William Easterly, Room N-11-043, World Bank, $1818 \mathrm{H}$ St. NW, Washington DC 20433 USA

I am grateful to participants in presentations at the NBER Workshop on Economic Growth and at the World Bank and to an anonymous referee for useful comments. 


\section{INTRODUCTION}

The economic literature on developing countries has long contained arguments that the large growth differentials among these countries could be explained by policy differences. Policies that directly distort relative prices and :esource allocation - such as tariffs, import quotas, controls on prices and interest rates, and discriminatory taxes - have been particularly singled out to explain differential performance of developing countries (Balassa (1985), Krueger (1978, 1983), Chenery et al. (1986)).

However, according to the standard neoclassical growth model due to Solow (1956), distortionary policier affect only the level of income (and that modestly as dramatized by the famous Harberger (riangles) and not its rate of growth. The alleged long-run growth effects of distortionary policy have also been dismissed in some "new" growth models (Lucas (1988) and Young (1991)). The natural conclusion is that distortionary policies are not that irnportant in explaining large differences in economic performance (Rodrik (1991), Sachs (1987)).'

In contrast, authors such as Romer (1986, 1989), Barro (1990), Barro and Sala-i-Martin (1993), Jones and Manuelli (1990), and Rebelo (1991) have presented models in which policies have significant effects on long-run growth. For example, in the area of fiscal policy, Barro (1990) bas discussed how tax rates can distort savings decisions and lower growth. while government seivices financed by those taxes can potentially raise private productivity and increase growth. A recent body of work has calculated the quantitative impact of tax policy on growth rates, with results that range from small (Lucas (i990)) to large (King and Rebelo (1990), Rebelo and Stokey (1993)) to very large (Jones. Manuelli, and Rossi (1993)).

However, the endogenous growth literanre has so far not given much attention to the distortions of resource allocation commonly induced by policies in developing countries, including

\footnotetext{
'The growth effects of discorsonery policies could be preserved in the Solow model if wa focused on the trenstion wo the steedy stats.

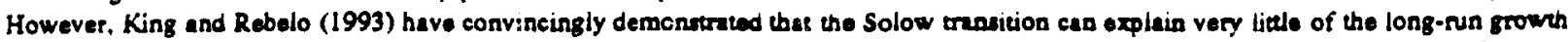
rate without genernang coumeriactul implication for the interat rate. Mantiw, Romer. and Weil (1992) genante a larger role for istanitional dynamice by upposing high capiul there. including burnn capital.
} 
both tax and nontax policies.: Tax systems in developing countries often have a very narrow base, because of widespread tax evasion and the small size of the formal sector (World Bank (1988)). Generation of revenue from this narrow base often implies very high tax rates. A few examples help illustrate this. More than 80 percent of income is : id to go unrepo.ted in Argentina (ibid.). Employment in the privats formal sector in Cote d'Ivoire amounts to only 1.4 percent of the population. Repeated attempts to increase tax revenue from the formal sector in Cote d'Ivoire have int with failure, as there is large-scale evasion of taxes - which tave an average effective tax rate of 48 percent (Chamley and Ghanem (1991)). Reliance on taxes on international trade is heavy in developing countries (particularly in Africa where it amounts to 35 percent of revenues), implying that the tax system penalizes the use of imporied inputs in production (World Bank (1988)). Although tax distortions are also significant in industria! countries (King and Fullerton (1984)), these examples suggest another order of magnitude for deveioping country distortions.

Besides explicit featıres of the tax system, there are numerous oth. ways that governments in developing countries intervene to create large distortions $o_{2}$ resource allocation. In addition to explicit taxes on trade, there are a host of other trade interventions frequently used, such as import quotas and licenses and multiple exchange rates. which imply distortions of prices of dumestic versus foreign goods, as well as among different types of foreign goods (World Bank (1987)). Foreign exchange controls lead to the creation of black markets in foreign exchange, where the exchange rate is a large multiple of the official exchange rate. Prior to reforms in Ghana in 1983. for example. the black market exchange rate was 44 times the official rate (Islam and Wetzel (1991)). Government marketing boards pay prices to domestic producers of export commodities that are a small fraction of the international price.

\footnotetext{
:An exception is Murphy, Shleifer, and Vishny (1991), which showa how rent-seeking in the presence of distortions can significandy lower grown
} 
Controls on nominal interest rates often result in large negative real interest rates. while quantitative credit allocation rules imply large subsidies for some types of capital and heavy implicit taxes on others. For example, credit for mortgage lending in Turkey was neavily subsidized in the early 1980 s, so that these borrowers paid highly negative real interest rates, while commercial credits for other types of loans carried real interest rates as high as 50 percent (World Bank (1989b)).

However, a large informal sector has sprung up side by side with the formal economy in many developing countries in response to distortionary government policies. De Snto (1989) bas convincingly shown how government regulation led to a thriving informal sector in Peru. Over half of urban employment in Africa is said to be in the infurmal sector (World Bank (1989a)). The illegal economy in Ghana in 1982 was estimated to have accounted for 32 percent of GDP (Islam and Wetzel (1991)) The informal sector often seems to provide a cushion to soften the impact of even the most extreme government policies. The depredations of the Amir. government in Uganda caused formal sector output to fall at 2 percent per year in 1970-78, but subsistence producticn continued to grow at 3.4 percent per year (Reynolds (1985)).

The multiple distortions described here cften cause severe misalignment of relative prices. For example domestic prices of some goods will be driven up through exorbitant tariffs or restrictive quotas while others receive preferential tariff or quota treatment, or are held down by domestic price controls. The model in this paper will show that the distortion of composition of the aggregate capital stock resulting from such interventions can have large growth effects, just as the tax-induced distortion of the ratio of physical to uunan capital affects growth in Jones, Manuelli, and Rossi (1993) and Rebelo and Stokey (1993). The price distortions can be measured diectly with the commodity-by-commodity price data collected by Summers and Heston (1988). This paper will propose a measure of relative price distortion relevant to long-run growth determination. and empirically examine its effects on growth. 
The paper is organized as follows. Section II will present the basic model relating distortions to growth, and show how it covers a variety of common distortionary policies. Section III will present empirical testing of some of the implications of the modet, deriving a new measure of the severity of distortion of the price syster. Section IV cuncludes.

\section{A MODEL OF ENDOGENOUS GROWTH WITH DISTORTIONARY POUICIES}

This section presents an endogenous growth model that attempts to capture some of the special features of distortionar.' government policy in developing countries. It postulates a model of constant returns to scale in reproducible capital, as in Rebelo (1991) and Barro (1990). ${ }^{3}$ Canital is broadly defined to include both physical and human capital. Two generic types of capital are defined io produce the single output - the types will be initially interpreted as formal and informal sector capital. The distortion will be defined initially as a sales tax on investment purchases in the formal sector. The relationship between this distortion rate and growth will then be discussed. Applications to other policies will then be considered. Throughout the paper, we assume that the economy is insulated from international financial markets, although trade in goods is considered. While the mociel is highiy stylized, the results seem to give insight into some of the developing country characteristics discussed above.

The Model

Equation (1) shows the production function for our analysis:

(1) $Y=A\left(Y K_{1}^{\epsilon}+(1-\gamma) K_{2}^{\epsilon}\right)^{\frac{1}{\epsilon}}$

\footnotetext{
'This type of model can also be seen as a convenuent approximation to Solow model with a very high share of capital including human capital), i: which policies have such large level effects that they appear to be grownth effects. Consunt reaums in reproducible capitai allows the deriveuon of a stendy state that approximates the tranational behavior of a Solow model with high capital ahare.
} 
Output is a CES function of the two generic types of capital, with elasticity of substitution $1 /(\epsilon-1)$. For simplicity, we assume population to be fixed throughout the analysis.

¿nitially we interpret the two types of capital as being formal and informal sector capitul, which are defined in terms of their lozation, ownership, and visibility to the tax authorities. We assume that the two types of capital can both be formed from the comestic good with zero installation cost, and that the economy is closed toth to foreign trade and capital flows (in the next section, we will show how some alternative interpretations ao not change the model). The distortion is a sales tax on formal sector investmen: purchases, which informal sector investment purchases evade.

We assume that idertical, infinitely-lived dynasties of producer-consumers maximize the present discounted value of the utility of future consumption:

$$
\int_{0}^{\infty} e^{-\mu} \frac{c^{1-\sigma}-1}{1-\sigma} d t
$$

Utility is given as an isoelastic function of total consumption $C$ where the intertemporal elasticity of substitution is $1 / \sigma$.

Consumption is given by the excess of income over investment spending:

$$
C=Y-(1+T) I_{1} \cdot I_{2}+T
$$

where $\tau$ is the rate of sales tax on purchases of investment goods of the first type. The variable $T$ is the lump-sum transfer of tax revenues back to consumers, ex-post equal to $r I_{1}$, but treated by the consumer as fixed. Growth is unaffect $t$, however, if the revenues are not rebated to the consumer. The equations of accumulation of capital are:

$$
\begin{aligned}
& \text { (4) } K_{1}=I_{1}-\delta K_{1} \\
& \text { (5) } K_{2}=I_{2}-\delta K_{2}
\end{aligned}
$$

where $\delta$ is the rate of depreciation, ass-med equal across capital types to simplify the algebra. We do not explicitly impose the condition that investment is irreversible. 
The $t$, torder conditions imply that the distortion will act as a wedge between the marginal products of the two types ef capital, as follows:

(6)

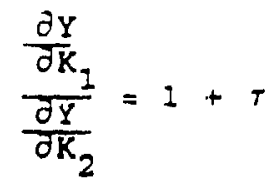

where $\tau$ is the rate $\rightarrow$ ax on investment in type 1 capital. This implies the following ratio of type 2 to type 1 capital (denoted $\Phi$ ), from (1) and (6):

(7) $\Phi=\frac{K_{2}}{K_{1}}=\left[\frac{(1-\gamma)(1+\tau)}{\gamma}\right]^{\frac{1}{1-\epsilon}}$

The distortion $\tau$ induces more of type 2 crital to be held relative to type 1 capital than is socially optimal. The elasticity of subsitution $(1 /(\epsilon-1))$ determines how strongly the ratio of capital inputs will l'espond to increases in the distortion.

In steady state, consumption and output will grow at the same rate, which will be given by:

$$
g=\frac{r_{2}-\delta-p}{\sigma}
$$

where $r_{2}$ is the marginal product of type 2 capital, given by the following:

(9) $\quad r_{2}=A(1-y)\left(\gamma \Phi^{-\epsilon}+1-\gamma\right)^{\frac{1}{\epsilon}}-1$

and $\Phi$ is the ratio of $K_{2}$ to $K_{1}$ given by (7). Growth is given by the familiar condition that optinal growth of consumption is equal to the difference between the net marginal product of capital and the rate of time preference, times the intertemporal elasticity of substitution. Since the marginal product of type 2 capital goes down when the ratio of type 2 to typt 1 capital increases, which occurs when type 1 capital is taxed more heavily, growth is unambiguously a negative function of the tax rate $\tau$.

A policy equivalence that follows immediately is that between a sales tax and an income tax. An income tax on the income from formal sector capital that is evaded by holders of informal sector 
capital will enter in an exactly analogous way as above (the income tax rate tequivalent iu a sales tax $\tau$ is $t=\tau /(1+\tau)){ }^{4}$

The nature of the relationship betwee. growth and distortion depends on the production elasticity of substitution between the two types of capita.. Figure 1 shows a simulation of growth rates for plausible parameter values with alternative production elasticities." The graphs are shown in te:ms of the equivalent income tax. With a high elasticity of substitution in production, even an income tax rate close to unity could still permit positive per capita growih. This is because when the elasticity of substitution is greater than one, neither input is essential to production. As the tax rate approache: one, investment in type $\perp$ capital asymptotically approaches zero. However, production is still possible relying only on type 2 capital, and so the rate of return to type 2 capital remains positive. While a nigh elasticity of substitution may seem implausible ir a model with only two inputs, it is more plausible in a multiple input production function where many types of taxed capital goods will have close substitutes in the informal sector. A high elasticity of subsitution between informal and formal capital could give insight into why even highly distorted economies could have less than catastrophic growth performance (such as Amin's Uganda, as cited earlier).

If the elastic. y of production is less than or equal to one, then the level of output and the rate of return to type 2 capital go to zero as the tax rate approaches one. As the tax rate goes to unity, economic agents will decumulate capital (assuming no irreversibility in invesiment) at a rate $((\delta+\rho) / \sigma)$. Growth also falls off more steeply at lower levels of the tax rate, as shown in figure 1 .

There is an analogous effect of the elasticity of substitution on the welfare loss associated with the distortionary tax. Figure 2 shows how the welfare loss is small at first, regardless of the

\footnotetext{
This equivalence is noted in another context by Atkinson and Stigliz (1980).

The parameter values used for the simulation are $A=.5, \delta=.05, y=5, c=2 / 3, \sigma=2$, and $\rho=1$. These values are arbitrarily chosen to reproduce plausible ranges of growth rates for illustrative purposes. The thape of the growrth-dinorion reiationatip is robuan to changes in these penmetorn except for the production elanticity of subrtitution (as discussed in the text) and the intertemporal elasticity of substivition (not discusead here, since it is well known to control the atr ngth of the aving respons is 4 , changes).
} 
elasticity. This follows from the fact that a laissez-faire zero tax policy is first-besi, which must imply that the der.vative of welfare with respect to the tax rate is zero at a zero tax rate. As the tax rate increases, welfare Fills off more sharply in the high elasticity case, then bottoms out at a finite level as the tax rate goes to one. This occurs because the taxed input is inessential, so even eiimination of the input's use unly leads tn a finite, albeit substantial, welfare loss. As the use of the input apprcaches zero, the marginal welfare loss of a higher tax $\mathrm{cn}$ that input is minimal. In the low substirutability case, the welfare loss is not bounded since the taxed input is essential for production.

This idealized framework suggest that one's strategy in a highly distorted economy should be influenced by one's assumption about substinutability of inputs in the production function. If one believes substitutability is high, one should concentrate on large reductions in large distortions, since moderate reductions have little benefit - a "Big Baig" is needed. If one believes substitutability is low, then any reduction in a large distortion will be beneficial - "gradualism" is a viable strategy.

It is also apparent from the maximization problem above that a sales tax that applies only to consumption purchases will have no effect on growth.? With exogenous labor supply, investment price distortions lower growth, but consumption price distortions do not. Since this result will be tested in the empirical analysis, it is worth examining how it compares with others in the literature. Consumption taxes that are rebated lump-sum to consumers affect growth in the endogenous labor supply models or Rebelo and Stokey (1993) and Jones, Manuelli, and Rossi (1993) (with Lucas

\footnotetext{
Welfare in ateady $\quad$ can be calculated as:

$$
W=\frac{\left(c_{k} K_{0}\right) 1-0}{1-\sigma}\left(\frac{1}{p-g(1-\sigma)}\right)
$$

where $K_{0}$ is the initial level of the total capital stock and $G_{k}$ is the ratio of consumption to toul capical stock, given as:

$$
\frac{C}{K_{1}+K_{2}}=\left(I_{2}-\delta\right)\left(1-\frac{1}{\sigma}\right)+\frac{\rho}{\sigma}+\frac{I_{2} \tau}{1+\Phi}
$$

it can be shown, however, that taxes on intermediate goods act much like uxes on investment goods and so de effect growth.
} 
$(1988,19 \overline{9} 0)$ "effective labor"). However, Rebelo and Stokey (1993) show that consumption taxes do not affect growth if they are not rebated to consumers. ${ }^{8}$

The fall in growth as a result of the tax on capital is similar to results obtained by Barro (1990), King and Rebelo.(1990), and Jones and Manuelli (1990). What is different here is that the fall in growth occurs not only through a fall in : vestment, but also in the efficiency of investment. An increase in the distortionary tax rate will lower growth even for a fixed rate of total investment to output (defined as the sum of the two types of investment as a ratio to output). Rebelo and Stokey (1993) and Jones, Manuelli, and Rossi (1993) show related compositional eifects of tax policy on the raitos of human to physical capital.

It is also apparem from (7)-(9) that a negative value of $\tau$, i.e. a subsidy to investment in type I capital financed by lump-sum taxation, will raise growth. Although lump-sum taxation is unrealistic, this result would also occur with a subsidy to one type of investment financed by a tax on consumption, siace the later has no growth effect. This is an example of the well-known possibility of immiserizing growth, since welfare is worsened but growth increases due to the subsidy. It is still true, however, that a bigher subsidy will lower growth for a given rate of saving and in wwiment; the increase in growth comes about through higher investment, partially offset by lower efficiency of investment.

\section{Self-financing subsidy and tax schemes}

Thus far we have considered only policies that implicitly tax one form of capital, assuming the proceeds are dissipated in lump-sum transfers. Other policies have the character of taxing one

\footnotetext{
This result is a consequesce of the restrictions on the utility function required to generate a ready state growrh path with a constant frection of time devoted to leirure, which requires that income and rubribution effects of wage changes cancel out. as pointed out earties by King, Plosser, and Rebelo (1988). Rebelo and Stokey (1993) also thow that if leisure is "quality-adjusted" (i.e. multiplied by the level of human capiul), then consumptionuxes do not affect growth regardlas of whether the taxes are rebated or not.
} 
type of capital and using the proceeds to subsidize another. For example, price controls act as a subsidy to the use of the cuntrolled-price goods, implicitly financed by taxes on other goods."

Using the framework of the previous section, we row assume investment in capital type 1 is taxed at rate $\tau$, and that the proceeds are used to finance a subsidy to capital type 2 at rate $\mathrm{s}$. The first-order condition ( 7 ) for the allocation of capital will be modified to be:

(11) $\Phi=\frac{K_{2}}{K_{1}}=\left[\left[\frac{1-\gamma}{\gamma}\right]\left[\frac{1+\tau}{1-s}\right]\right]^{\frac{1}{1-\tau}}$

The requirement that the scheme be self-financing imposes the condition:

(12) $\frac{K_{2}}{K_{1}}=\frac{\tau}{s}$

For a given subsidy rate s, (11) determines the allocation of capital between types and (12) determines the tax rate necessary to finance the subsidy. The growth rate expression (8) will now be modified to be:

(13) $g=\frac{\frac{I_{2}}{1-S}-\delta-\rho}{\sigma}$

An increase in the self-financing subsidy will have two offsetting effects on the growth rate. The increase in the subsidy makes accumulation of type 2 capital more attractive, and tends to raise growth, as in the previous section. However, the before-subsidy marginal product of type 2 capital will fal: because of the substitution from type 1 to type 2 capital, which is induced by the subsidy and by the tax necescary to finance the subsidy. Appendix I shows that the second effect always outweighs the first: the net effect is that growth unambiguously falls with an increase in the rate of subsidy financed by a tax on capital.

\footnotetext{
This is presumung that the price controls are accompanied by budgetary transfers to compensate the producer for the lower proce. Otherwise, shortages and black market preces arise. Just as in the case of foreign exchange controls (see below).
} 
Other policy applications

The analysis has been presented thus far in terms of a sales tax or subsidy (or equivalent

income tax) on formal sector capital in the presence of an informal sector. We now show some other examples of policies that give similar results, illustrating that the framework is general enough to consider a range of distortionary policies.

\section{Financial repression}

Controls on interest rates below market levels generally lead to quantitative credit allocation by the formal financial system, combined with a flourishing "curb" market formed by consumers or producers who lend to each other at market rates. The quantitative credit allocation rules are of 9 a designed to promote certain kinds of activities, for example, small-scale enterprises or agriculture (World Bank (1989b)). In terms of this model, we can th uk of a credit subsidy being given to all who invest in a particular kind of capital goods (type 2 capital). We can assume that the subsidy is financed by an implicit tax on the non-subsidized capital (type 1 capital).

2. Trade policy

We could next redefine the two types of capital to be imported capital $\left(K_{1}\right)$ and domestically produced capital $\left(\mathrm{K}_{2}\right)$, and redefine the tax rate $\tau$ as a tariff on imported goods. We assune that the domestic good is also traded internationally and that the country is a price-taker (the international price ratio of the two goods is fixed at unity for convenience). The tariff then acts as a tax on type 1 investment goods. Equaily, both types of goods could be imported, and the tariff structure imply a tax-cum-subsidy scheme in favor of some types of investment goods. Thus, both a higher level and a greater dispersion of tariffs (or equivalent quotas) will result in lower growth according to this model.

3. Exchange rate policy

When exchange rate controls in developing countries lead to black markets in foreign exchange, foreign exchange is typically allocated at the official rate so as to favor certain activities. 
In terms of this model, a foreign exchange allocation that grants foreign exchange at the official rates for goods that make up capital type 2, and does not grant any for investment in type 1 goods, will imply a tax-cum-subsidy scheme with the wedge between the two goods equal to the black mariet exchange rate premium.

\section{Price controls}

Price controls on particular goods are a common feature of developing country po!icies. For example, coal prices are often controlled to be below international levels in many countries (World Bank (1988)). The coal subsidy is financed by other revenues from the government budget. This is equivalent to the tax cum subsidy scheme discussed in the previous section. Since distortions 2 . and 3. above also affect the price system, this suggests that a comprehensive measure is needed to capture all of the complicated and possibly offsetting relative price distortions inherent in government policies.

\section{EMPIRICAL RESULTS}

Although a large literature exists relating policy variables to growth, there have been few attempts to measure price distortions directly. This section proposes a new measure of relative price distortion and tests its relation to growth, along with other distortion measures used in other studies. We discuss first the variables, and then discuss the results.

\section{Variables}

1. Price distortions

One way to measure indirect distortions of prices. like those analyzed in the previous section. would be to look directly at observed retail prices across countries. Summers and Heston (1988) collected data on 1980 benchmark prices relative to the U.S. for 57 countries and 151 commodities. 
We construct a measure of the variance of relative prices across commodities for each country and interpret this as a measure of overall distortion of the pice system. There are two adjustments that need to be made. First, the variance of each commodity's price across countries due to differences in natural resource endowments needs to be removed. Although theoretically this is necessary only for nontraded commodities, even traded comroodities' domestic price may contain a nontraded component due to retailing and transportation costs. This is done by isolating the orthogonal component of each of the log of the 151 prices with respect to per capita income. Secondly, thr iry predicts that oniy distortions in prices of intermediate inputs and investment goods matter. We $i \quad$ ' $\cdot$ iruplication of the theory by computing separately cross-commodity variances for consumptiol : $0 \mathrm{OC}$ ' and for investment/intermediate goods (human capital inputs such as health and education were $z^{1} / s 0$ included under investment - Appendix III contains the list of commodities). We use the same data to compute the expenditure-weighted mean of the orthogonalized logs of relative input/investment prices. We then compute for each country the expenditure-weighted sum of squared deviations of each commodity's orthogonalized log price from the log mean. ${ }^{10}$

Appendix II shows the variance and mean of input prices for each country. The countries with the highest variance of relative input prices in 1980 are Sri Lanka, Venezuela, Peru, Bolivia, and Indonesia. All of these countries partially compensate with cheap prices for inputs and investment goods. Cote d'Ivcire, Nigeria, Senegal, and Cameroon have the highest average input prices. Industrial countries generally have low distortions of relative input prices, and neither very high nor very low average input prices. Table 1 shows the mean and variance of these and the other distortion measures.

\footnotetext{
This is similer to the clever procedure followed by Aitken (1991) to compute a measure of distoruon. However, Aitken eggregates commodities into 16 categones before computing cross-commodity variances, he does not diatingush between conampuon and invertment goods. and he does not relate his index to growth. I am grateful to Brian Aitken for supplying the Summers-Heston price dau in convenient format.
} 


\begin{tabular}{||l|l|l|l|}
\hline $\begin{array}{l}\text { Table 1: Descriptive statistics for } \\
\text { distortion measures }\end{array}$ & $\begin{array}{l}\text { Sample } \\
\text { mean }\end{array}$ & $\begin{array}{l}\text { Sample } \\
\text { standard } \\
\text { deviation }\end{array}$ & $\begin{array}{l}\text { Number of } \\
\text { countries in } \\
\text { sample }\end{array}$ \\
\hline $\begin{array}{l}\text { Mean across input categories of log of ratio } \\
\text { of input prices to U.S. price (orthogonal } \\
\text { component to income), 1980 }\end{array}$ & -0.230 & 0.458 & 57 \\
\hline $\begin{array}{l}\text { Variance across input categories of log of } \\
\text { ratio of input prices to U.S. price } \\
\text { (orthogonal component to income), 1980 }\end{array}$ & 0.241 & 0.158 & 57 \\
\hline $\begin{array}{l}\text { Mean across consumption categories of log } \\
\text { of ratio of consumption prices to U.S. price } \\
\text { (orthogonal component to income), 1980 }\end{array}$ & -0.160 & 0.333 & 57 \\
\hline $\begin{array}{l}\text { Variance across consumption categories of } \\
\text { log of ratio of input prices to U.S. price } \\
\text { (orthogonal component to income), 1980 }\end{array}$ & 0.230 & 0.149 & 57 \\
\hline $\begin{array}{l}\text { Log of ratio of black market to official } \\
\text { exchange rate, average 1970-85 }\end{array}$ & 0.194 & 0.251 & 106 \\
\hline $\begin{array}{l}\text { Average real interest rate, 1970-85 (used to } \\
\text { define financial repression dummy) }\end{array}$ & -3.58 & 8.95 & 53 \\
\hline
\end{tabular}


Earlier results for growth using the Summers and Heston price data were found by Dollar (1992) and De Long and Summers (1991). Dollar tested a measure of exchange rate overvaluation constructed as the average price level in each country relative to the US, corrected for differences in resource endowments, and found overvaluation to significantly lower gro, th. De Long and Summers found that high relative equipment prices significantly lower growth.

\section{Financial distortions}

We extend a dataset from Gelb (1989) of real interest rates for developing countries, adding observations for developed countries. A highly negative real interest rate is interpreted to imply the existence of nominal interest rate controls (moderately negative real interest rates have been observed for reasonably long periods even in countries with uncontrolled interest rates). We follow World Bank (1989b) in defining "financial repression" as an average real interest rate below -5 percent over 1970-85 (jeriod varies depending on data availability) - there are 14 such countries (out of 53). We will examine robustness to other cutoff points as well as to the use of a continuous variable. Gelb (1989) found real interest rates to be significantly correlated with growth. Fischer $(1983,1991)$ and Kormendi and Meguire (1985) report a possibly related finding of a negative effect of inflation on growth.

\section{Black market premium}

The black market premium is defined as the log of the ratio of the black market to the official rate over roughly $1970-85$ (period varies with data availability), based on data from Pick's Currency Yearbook and the World Bank. Levine and Renelt (1992) found this variable to have a significant effect on investment, although not on growth: Easterly (1991) found it to be a good predictor of whether countries are caught in a low-level equilibrium trap. 


\section{Government consumption}

Government consumption has been found to be negatively related to growth by Barro (1991), Grier and Tullock (1989), Landau (1986), and Murphy, Shleifer, and Vishny (1991). In terms of the model in section II, government consumption is an indicator of high taxes on the formal sector.

\section{Barro correlates}

In addition to these measures of distortion of resource allocation, we also test for correlates reported by other studies, taking Barro (1991) as the benchmark study. We focus on initial income, primary enroliment, and secondary enrollment. We also use the same dependent variable (per capita growth 1970-85 from Summers and Heston (1988)) as Barro for ease of comparison. Finally, the investment rate (also from Barro/Summers and Heston) is added to the equation to test the implication of the mode! that distortions lower growth concrolling for investment.

\section{Empirical results}

Table 2 shows the results. Both the mean input price and the variance of input prices across commodities are significant. The variance result is consistent with the prediction of the model in section II - in a multiple input world, distortions of relative prices away from world prices will lower growth. The magnitude of the variance coefficient is such that increasing the variance of relative prices from the sample mean of .24 by one standard deviation to .40 will lower growth by 1.2 percentage points.

The significance of the mean input price is reminiscent of the De Long and Summers (1991) finding that cheap investment equipment is good for growth. Here we find more generally that cheap inputs -- including intermediate inputs, education, health, buildings and equipment investment - are good for growth. This result confirms the prediction of the model that subsidizing inputs is a feasible way to raise growth (although immiserizing unless there are externalities). When the equipment price 
variable is added, neither price is significant -- we cannot distinguish between the two - but the variance of input prices continues to be significant (regression VI).

The financial repression dummy is also highly significant, with a coefficient indicating a loss of about 1.5 percentage points in growth due to financial repression. Th ${ }^{\prime}$ does not appear to be a proxy for high inflation, which was insignificant when tested separately. The implicit taxes from highly negative real interest rates apparently fall on productive investment. If we accept regression I as a valid reduced form, these three distortion variables (with government consumption) explain half of the cross-section var.dise in growth rates.

The financial repression dummy, and the mean and variance of input prices continue to be significant when investment is added (regressions II and III). Growth falls for a given rate of investment falls when relative input prices are heavily distorted, when inputs are expensive, and when interest rates are repressed. The significance of the financial repression dummy and the variance of input prices confirms the efficiency effects predicted by the model in section II. The significance of mean input prices does not at first seem to conform to the prediction of the model that a uniform tax on all inputs should affect the level of investment, but not the efficiency of investment. However, since investment here includes only physical capital, the result may reflect higher productivity of physical capital with cheaper intermediate and human capital inputs.

Because investment is likely endogenous, we show also a regression (IIIa) with an instrumental variables estirator, using as instruments for investment the other right-hand side variables as well as continent dummies for Africa and Latin America, a dummy variable for oil producers, and the population size in 1960. The coefficient on investment is increased, but the coefficients on the other variables are roughly unchanged. 
Table 2: Regression results, growth and distonion

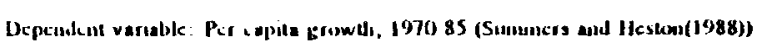

\begin{tabular}{|c|c|c|c|c|c|c|c|c|c|c|c|c|c|c|c|}
\hline Mesrososent. & $\begin{array}{l}\text { Varmble. } \\
\text { Cansters }\end{array}$ & 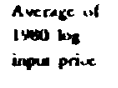 & $\begin{array}{l}\text { Varume of } \\
\text { isto bo } \\
\text { inper prices }\end{array}$ & 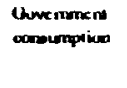 & 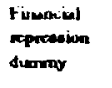 & 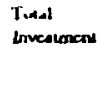 & 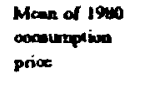 & 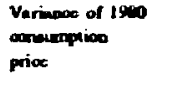 & 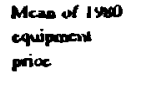 & $\begin{array}{l}\text { Alack } \\
\text { marke } \\
\text { premives }\end{array}$ & 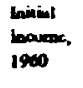 & 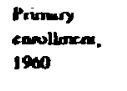 & 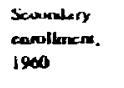 & KZZKBAK2 & $\begin{array}{l}\text { Number int } \\
\text { obecrovesore }\end{array}$ \\
\hline \multirow[t]{2}{*}{1} & Dow1 & 0024 & ouss & o oss & 0014 & & & & & & & & & us2 & 34 \\
\hline & $(084)$ & $(207)$ & $(-215)$ & $(-1.50)$ & $(200)$ & & & & & & & & & 040 & \\
\hline \multirow[t]{2}{*}{ "I } & 0010 & 0020 & ocos & $003 i$ & 0016 & 0.092 & & & & & & & & osy & 34 \\
\hline & (1) 38) & (30s) & $(-194)$ & $(0.70)$ & $(-23)$ & (26) & & & & & & & & oss & \\
\hline \multirow[t]{2}{*}{$m$} & 0010 & 0027 & 0006 & & 0016 & 0.058 & & & & & & & & 0.59 & 36 \\
\hline & (1 0.2) & (3.99) & $(-2.18)$ & & $(-236)$ & 1299 & & & & & & & & ost & \\
\hline \multirow[t]{2}{*}{ Mtar(tSt S) } & 0119 & 0027 & 0034 & & 0011 & 0186 & & & & & & & & osi & 34 \\
\hline & (0s) & $(40,4)$ & $1226)$ & & $1.25 n$ & $11.99 n$ & & & & & & & & 045 & \\
\hline \multirow[t]{2}{*}{ IV } & 0025 & o01y & 0.054 & $\operatorname{son}$ & 0.010 & & & & & 0.015 & 0.006 & 0.016 & ooss & $0 \infty$ & sx \\
\hline & $(18)$ & $(31)$ & $(2.03)$ & $(075)$ & $(-1.51)$ & & & & & $(0.7)$ & $(-2.39)$ & $(100)$ & (226) & 0.9 & \\
\hline \multirow{4}{*}{ 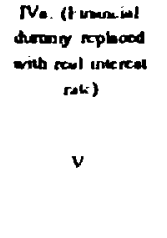 } & o on? & 0018 & 0 ors & 0.033 & .0006 & & & & & 0021 & 0.000 & 0.015 & 0036 & a) & 3 \\
\hline & $(201)$ & (33) & $\left(\left\{y_{3}\right)\right.$ & $(090)$ & (24) & & & & & $\left(1 m_{3}\right)$ & 12.79 & (1.73) & $(241)$ & 32 & \\
\hline & 0031 & 0032 & 0.119 & & 0022 & & 0.012 & 0.006 & & & & & & ast & 38 \\
\hline & $(083)$ & $(-234)$ & $(-3.54)$ & & $(212)$ & & o.m & (11.60) & & & & & & 0 so & \\
\hline \multirow[t]{2}{*}{ vi } & 0012 & o ory & 0033 & & -014 & & & & 0013 & & & & & 050 & 38 \\
\hline & (32) & $(010)$ & $(-2.14)$ & & $(209)$ & & & & $(040)$ & & & & & $0+4$ & \\
\hline \multirow[t]{2}{*}{ vil } & o ave & & & $00 \cos 8$ & J 018 & & & & & 0.030 & & & & 042 & "1 \\
\hline & $104 n$ & & & $(-3.1)$ & $(24)$ & & & & & 1280 & & & & 038 & \\
\hline \multirow[t]{2}{*}{ VIL (FI)UM < $<2)$} & $0 \times 0$ & & & 0001 & 0.011 & & & & & .037 & & & & 038 & 31 \\
\hline & 1039 & & & $(-300)$ & $(.183)$ & & & & & $(1.4)$ & & & & 034 & \\
\hline
\end{tabular}

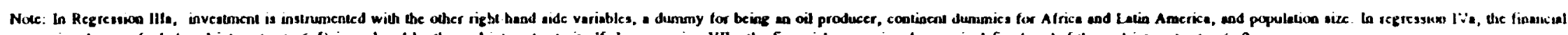

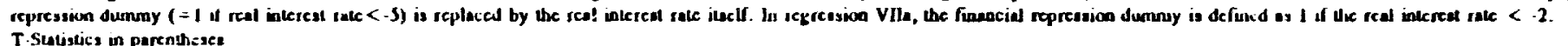

T.Salistics in parentheser

All cesulis reponced using Whice heccrusiedasticity - comsistent coveriance matrices 
Table 2 Variable definitions:

Average input price: Expenditure-weighted average across categories of inputs and investment goods listed in Appendix III for 1980 orthogonalized log of dolıar price relative to the U.S.

Variance of input prices: Expenditure weighted variance across input and investment good categories for 1980 orthogonalized log of dollar price relative to the US.

Government consumption: Summers and Haston ratio of real government consumption to GDP, 1970-85 (Barro variable HSGOV)

Financial repression dummy: 1 if country has average real interest rate for 1970-85 less than -5 percent, 0 otherwise (periods of average may vary depending on data availability) [From Gelb (1989) and World Bank data] In regression IVa, the dummy variable is replaced by the actual average real interest rate over 1970-85 (notice interpretation of the sign of coefficient will be reversed); in regression VIIa, the dummy variable is replaced by a dummy variable where the dummy is equal to one if the average reai interest rate is less than -2 over $1970-85$

Total investment: Summers and Heston ratio of real investment to GDP (Barro variable HSINV)

Mean consumption price: Exper diture-weighted average across categories of consumption goods listed in Appendix II for 1980 orthogonalized log of dollar price relative to the U.S.

Variance of consumption price: Expenditure-weighted variance across categories of consumption goods for 1980 orthogonalized log of dollar price relative to the U.S.

Mean of equipment price: Expenditure-weighted average across categories of equipment investment for 1980 orthogonalized log of dollar price relative to the U.S.

Black market premium: Log of ratio of black market to official exchange rate [World Bank data]

Initial income: Summers and Heston real per capita GDP in 1960 (Barro variable GDP60)

Primary enrollment: Barro variable PRIM60

Secondary enrollment: Barro variable SEC60

Note: orthogonalization is with respect to log of per capita income. 
When we add the analogous measures of the mean and cross-commodity variance of consumption good prices, we find that they are insignificant, while the mean and variance of input prices continue to be significant (regression V). This is consistent with the prediction of the model that consumption price distortions do not matter but input price distortions do. ${ }^{11}$

The significance of the mean and variance of input prices is robust to the inclusion of correlates reported by Barro (regression IV). The same cannot be said for the financial repression dummy, whose significance is weakened when the Barro correlates are added.

We also examine the robustness of the resuli un the financial repression variable by considering alternative definitions of "repression". Redefining repression as less than a -2 percent real rate of interest increases the number of repression cases from 11 to 19 countries in the sample of 51 (regression VDa). The redefined repression variable has the same sign but generally falls short of significance. On the other hand, a continuous variasle for the real interest rate is still significant at roughly the same or higher level as the current dummy variable. The continuous variable retains significance in the Barro regression (regression IVa). Note that because of the redefinition of the variable, the sign here is the opposite of the dummy variable but still has the interpretation that negarive real interest rates are bad for growth. The continuous variable may be more likely than the dummy variable to capture other sources of variation than just the degree of financial repression, however. We conclude the evidence for effects of financial distortions on growth is suggestive, but far from conclusive.

There is some evidence for effects of other distortion variables on growth. The black market premium is significant in an equation with financial repression and government spending (regression VII), but its significance disappears when the mean and variance of relative input prices (and the

\footnotetext{
"We also tried Dollar's (1992) measure of exchange rate overvalustion, which is closely related to the mean consumption price, and found it to be insignifeent.
} 
Barro correlates) are added (regression IV). The same is true for the share of government, whose significance also disappears when investment is added (regression In).

The strongest results are those for the new measures of price distortion. The results can be illustrated by looking at three data points: Ct:'e, Korea, and Zambia, using regression III as the benchmark. All three had roughly the same investment rates, around 27 percent of GDP, but Korea had high growth (6\%) and Chile (0\%) and Zambia (-2\%) had low growth. A significant portion of the difference in growth rates can be explained by regression III. Chile and Zambia both had high negative real interest rates (in Chile's case, mainly during the 70-73 Allende regime and its aftermath), which itself lowers growth by 1.6 percentage points. Korea and Chile both implicitly subsidized input investment goods heavily on average, while Zambia implicitly taxed them - this explains over 2 percentage points of Zambia's lower growth compared to Korea. On the other hand, while Korea and Zambia only had moderately distorted prices between types of inputs, Chile's were heavily distorted. The high variance of input prices cost Chile 1.6 percentage points of growth compared to Korea. It is interesting that Korea was not a case of "getting prices right", but rather one of heavy subsidization of inputs, which implies growth was "too high" by about one and a half percentage points if no externalities are assumed.

\section{CONCLUSIONS}

A simple model of endogenous growth with two types of capital shows that distortions of relative input prices can have large effects on growth and welfare. The magnitude of the effect depends on the production elasticity of substitution. With high substitutability, the effects on growth and welfare are bounded -- albeit possibly large -- no matter how high the rate of distortion. Subsidization of inputs and investment goods can raise growth, even though they worsen welfare. But a subsidy to one capital good financed by a tax on another capital good unambiguously lowers 
growth. Empirical results show strong negative effects of the variance of relative prices of investment goods across sector, while also confirming and extending earlier results that penalizing investment goods and distorting :.nancial markets lowers growth. 


\section{APPENDIX I: effect on growth of a self-financing subsidy-cum-tax policy}

As outlined in the text, an increase in a subsidy to type II capital financed by an increased tax rate on type I capital always lowers growth. To stow this, it is sufficient to s'ow that the tax increase necessary to finance the increased subsidy is greater than the tax increase that would just maintain the growth rate fixed (since a tax increase by itself unambiguously lowers growth;. From (11) and (12) in the text, the balanced budget requirement means that $s$ and $\tau$ must satisfy:

(A.1) $\frac{t}{s}=\left[\left(\frac{1-Y}{Y}\right)\left(\frac{1+\tau}{1-s}\right)\right]^{\frac{1}{1-\tau}}$

The derivative of $\tau$ with respect to $s$ from (A.1) (using (A.1) itself to simplify) is:

(A.2) $\frac{d \tau}{r^{\prime} S}=\frac{\frac{\tau}{S}+\left(\frac{1}{1-\epsilon}\right)\left(\frac{\tau}{1-s}\right)}{1-\left(\frac{1}{1-\epsilon}\right)\left(\frac{\tau}{1+\tau}\right)}$

Note th it it.$>0$ (elasticity of substitution $>1$ ), then as the tax rate approaches $(1-\epsilon) / \epsilon$, the further increase in ax rate necessary to finance the subsidy goes to infinity. With elastic substitution possibilities, inere is a limit on the subsidy rate that is feasible under a subsidy-cum-tax scheme. If $\epsilon \leq 0$, then any subsidy rate less than one is financeable.

From (3) in the text, the combination of $\tau$ and $s$ that yield a constant growth rate $g$ is given by:

(A.3) $\frac{r_{2}}{1-s}\left\{\frac{k_{2}}{k_{1}}\{\tau, s\}\right\}=8+p+\sigma g$

where the \{\} denotes "function of ". The right-hand side of (A.3) is constant by assumption; $g$ is the growth rate consistent with the initial $\tau$ and $s$. The derivative of $\tau$ with respect to $s$ from (A.3) can be radically simplified to:

(A.4) $\frac{d \tau}{d s}=\frac{\tau}{s}$

where we use the fact that $\frac{k_{2}}{k^{2}}=\tau / s$ at the initial point. Comparing the derivatives in (A.2) and (A.4), we see that (A.2) is unambiguously larger. This says that the tax increase necessary to raise the revenue to finance a given subsidy rate increase is larger than the tax rate increase that would just maintain the growth rate constant. Since an increase in the tax rate for a given rate of subsidy always lowers growth, this says that an increase in the subsidy rate on type II capital financed by an increase in the tax rate on type I capital unambiguously lowers growth. 
Appendix II Mesures of dirorion by country

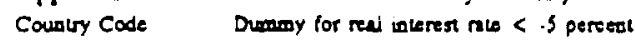

\section{A2O}

AUs

AUT

BEI

BOD

SOL

BRA

BWA

ENH

CrI.

CIV

on

COL

CRI

DEU

Dres

DOM

sey

EOY

ExP

ETH

FRA

OSR

GKA

GRC

ond

hOSO

HOND
HVO

DN

DND

DI

is

TA

INM

IPY

Kar

LeA

wo

$1 . A R$
$M D O$

MEX

MLI

MWI

MYS

NOA

ND

NOR

OMN

PAK

PAN

PER

PKL

POL

PRT

SEN

STE

stV

swe

TIU

TTO

TUN

TUR

TZA

USA

zer

ane
1.0000

0.0000

0.0000

0.0000

0.0000

1,0000

0.0000

0.000

1.000

0.0000

0.0000

0.0000

0.0000

1.0000

0.000

0.000

0.0000

0.0000

1.0000

0.0000

0.0000

0.0000

0.0000

0.0000

0.0000

0.0000

1.0000

0.0000

0.000

0.0000

0.0000

0.0000

1.0000

0.0000

0.0000

1,000

0.0000

0.0000

0.0000

$0.0 \times 0$

1.0000

0.0000

1.0000

1000

0.0000

0.0000

0.0000

1.0000

0000

0.0000

1.0000

1.0000

0.0000
Verience of log apus preses acroul commoditues

0.000

0.1160

0.00057

0.45

$0.201 \times$

0.2919

0.20076

0.45

0.2075

02309

0.7706

0.2017

0.0000

0.0000

0.270

0.2401

0.10100

0.09130

0.1841

0.00534

0.0059

0.11019

$0.25 \times 4$

0.304

0.2131

0.4004

0.2615

0.003

0.162

$0.000 s$

0.2704

0.1218

0.21275

$0.2005 s$

0.0000

0.2575

0.2006

000

0.1977

0.2005

0.00013

0.1000

$03+139$

0.2161

0.5977

0.36000

0.1007

0.3715

0.13039

0.1906

0.3576

0.22011

0.2120

0.0675

0.75701

0.257

0.201
Average of loe mpur pree

0.11346

021361

0.11262

$0.0013 !$

0.074

0.714

0.1250

0.00200

0.61117

0.309

0.1603

0.000

0.21025

0.240

0.577

0.00

0.0740

0.3019

$0.10 \%$

$0.16 \mathrm{~m}$

0.14013

$0.100 \%$

$0.75 \operatorname{sen}$

$0.3 \times 21$

0.4920

0.7011

0.0078

0.0000

0.2645

0.114

0.190

$0.000 \mathrm{~s}$

0.5095

$-1.7395$

0.0751

o.enss

c . 106

0.19531

0.00004

0.36574

0.25131

0.1659

$-1.20$

0.400

0.5579

0.6910

0.325

0.33600

0.4115

0.71495

0.11006

00

$035 \pi$

odart

osion

0.21166

0.16100 
Agpendix II Goode for Calculation of songumprion and insut price evereges and vaneaces

Consumpaoa Goods

Rice

Meal, wher cereals

Bread

Bigcuics, eskes, etc.

Cereal preparation

Macuron, spegherai

Froah beet, veal

Froah lamb, couroo

Freals pork

Freah pouttry

Otber tresh meat

Frozen and relied out

Fresh and trozen fiv

Canned fist

Fresh milk

Milk products

Eg81, eg8 products

Buter

Margarine, edible oil

Lard, edible fat

Fresh tropical fruits

Other fresh fruits

Fresh vegetibles

Fruit other than fresh

Vegeubles other then tresh

Tubers, including poutoos

Coffee

Tes

Cocos

Suger

Jem, nyrup, honey

Cbocolate, ice cream

Salt, spices, unces

Non-alcoholic bevernges

Spirits

Wne, cider

Beer

Cigareates

Cigars, tobnceo, souft

Clothing reterials

Men's clothing

Women's cloching

Boy' and girls' cloching

Mea' and boy' uaderwear

Women' acd gitls' underwear

Haberdacbery, millinery

Cloching rentel end repais

Meq's foorwent

Women's foorweer

Children's foorwent

Foorwest, repair

Fumiare Fixares

Floot coverings

Housenold texules, ece.

Refrigerston, troezer

Washing appliances

Cooking appliancea

Heating appliance

Clearing eppliences

Other household appliances

Household utensiis

Nondurable hourehold goods

Domestic services

Househuld services

Barber and beaury thops

Toilet arrseles

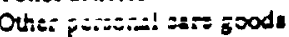

Resuurani, cafee

Hotels, lodgings

Other services

Expendiares of reaidente abroed

Onv and nw z-parily dwellings

Muttifamily dwellings

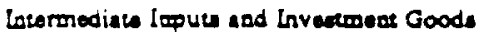

Druge, medical preparation

Medical ruppliea

Therapeutic equipmeas

Physicisn' equiponeot

Dentisu' iervices

Nurses' services

Horpicals

Personal aucooobiles

Other perwoal trapon

Tles, abes, sccaseries

Aueomobile ropair

Gesoline, oid, strenes

Parting, 'olls, ete.

Locel truapor

Reil transport

Bus tranpors

Air trappon

Porral communiestion

Telepbone, calestuph

Books, papers, mngexines

Sutionery

Firt end second-loval mebert

Colloge cencbers

Pbyrical facilities for education

Educational boots, rupplies

Orber educational expendieures

Hotels

Induatrial buildingt

Commervisl buildings

Ortce building

Educational buildings

Hompieal building

Agriculand buildings

Oeber buiddines

Rouds, trowe, bighwavs

Transpor and usility lines

Other contruction

Lend improveroex

Locomotives

Obber allway vebicles

Pacueger suwomobiles

Trucks, buses, trilen

Airetef?

Stips, bats

Oet eneport equipmen

Engioes, witiones

Tretors

Other agriculestal machinery

Oftee mechisery

Melniworting mechinaty

Coorersesiod, mining mehinery

Special induscrial methinery

Electrical tranmiation equipment

Communications equipmear

Other electrical equipraem

Inronutrenes

Furaure, freures

Orber durable goods 


\section{REFERENCES}

Aitken, B., 1991, Measuring Trade Policy Intervention: A Cross-Country Index of Relative Price Distortion, Working Paper 838, World Bank.

Atkinson, A., and J. E. Stiglitz, 1980, Lectures on Public Economics (McGraw-Hill, New York)

Balassa, B., 1985, Exports, Policy Choices, and Economic Growth in Developing Countries After the 1973 Oil Shock, Journal of Development Economics 18, 23-35.

Barto, R. J., 1991, Economic Growth in a Cross Section of Countries, Quarterly Journal of Economics 106, 407-444.

1990, Government Spending in a Simple Model of Endogenous Growth, Journal of Political Economy 98, 5103-5125.

and Sala-i-Martin, X., 1993, Public Finance in Models of Economic Growth, Review of Economic Studies, forthcoming.

Chamley, C. and H. Ghanem, 1991, Fiscal Policy with Fixed Nominal Exchange Rates: Cote d'Ivoire, Working Paper 658, World Bank.

Chenery, H., S. Robinson, and M. Syrquin, 1986, Industrialization and Growth: A Comparative Study (Oxford University Press, New York)

De Long, J. B. and L. H. Summers, 1991, Equipment Investment and Economic Growth, Quarterly Journal of Economics 106, 407-444.

de Soto, H., 1989, The Other Path: the Invisible Revolution in the Third World, (Harper and Row, New Yo:k)

Dollar, D., 1992. Outward-Oriented Developing Economies Really Do Grow More Rapidly: Evidence from 95 LDCs, 1976-85, Economic Development and Cultural Change 40, 523-544

Easterly, W., 1991, Economic Stagnation, Fixed Factors, and Policy Thresholds, mimeo, World Bank

Fischer, S., 1983, Inflation and Growth, NBER Working Paper No. 1235, Cambridge, MA: NBER. 1991, Growth, Macroeconomics, and Development, in: S. Fischer and O. Blanchard, eds., NBER Macroeconomics Annual 1991 (MIT Press, Cambridge)

Gelb. A., 1989, A Cross-Section Analysis of Financial Policies, Efficiency and Growth. Working Paper 202, World Bank.

Grier. K. and G. Tullock, 1989, An Empirical Analysis of Crnss-National Economic Growth, 19511980, Journal of Monetary Economics 24, 259-974. 
Islam, R. and D. Wetzel. 1991, Macroeconomics of the Public Sector Deficit: the Case of Ghana, Working Paper 672, World Bank

Jones, L. and R. Manuelli, 1990, A Convex Model of Equilibrium Growth. Journal of Political Economy 78, 1008-38.

Jones, L., R.E. Manuelli, and P.E. Rnssi. 1993, Optimal Taxation in Models of Endogenous Growth, Journal of Political Economy 101 (forthcoming)

King, M. A. and Fullerton, D., eds, 1984, The Taxation of Income from Capital: A Comparative Study of the U.S., U.K., Sweden arid West Germany, Chicago: University of Chicago Press.

King, R. and S. Rebelo, 1990, Public Policy and Economic Growth: Developing Neoclassical Implications, Journal of Politica: Economy 98, S126-S150.

and 1993. Transitional Dynamics and Economic Growth in the Neociassical Mrodel, American Economic Review, forthcoming.

King, R., C. Plosser, and S. Rebelo, 1988, Production, Growth and Business Cycles I. The Basic Neoclassical Model, Journal of Monetary Economics 21, 195-232.

Kormendi, R. and P. Meguire, 1985, Macroeconomic Determinants of Growth: Cross- Country Evidence, Journal of Monetary Economics 16, 141-163.

Krueger, A. O., 1978, Foreign trade Regimes and Economic Development: Liberalization Attempts and Consequences (NBER, Cambridge, MA) , 1983, Trade and Employment in Developing Countries, 3. Synthesis and Conclusions (University of Chicago Press, Chicago)

Landau, D., 1986, Government and Economic Growth in the Less Developed Countries: An Empirical Study for 1960-80, Economic Development and Cultural Change 35, 35-75.

Levine, R. and D. Renelt, 1992, A Sensitivity Analysis of Cross-Country Growth Regressions, American Economic Review 82, 942-63.

Lucas, R. E., 1988, On the Mechanics of Economic Deveiopment, Journal of Monetary Economics 22, $3-42$.

1990, Supply-side Economics: an Analytical Review, Oxford Economic Papers 42, 293316.

Mankiw, N. G., D. Romer, and D.Weil, 1992, A Contribution to the Empirics of Economic Growth, Quarteriy Journal of Economics 107, 407-438.

Murphy, K., A. Shleifer, and R. Vishny, 1991, The Allocation of Talent: Implications for Growth, Quarterly Journal of Economics 106, 503-530. 
Rebelo. S, 1991, Long Run Policy Analysis and Long Run Growth, Journal of Political Economy 99. 500-521.

and N. Stokey, 1993, Growth Effects of Flat-rate Taxes, mimeo. University of Chicago.

Reynolds, L. G, 1985, Economic Growth in the Third World, 1850-1980, (Yale University Press, New Haven)

Rodrik, D., 1991, Closing the Productivity Gap: Does Trade Liberalization Really Help?, in: G. Helleiner, ed., Trade Policy, Industrialization, and Development: A Reconsideration (Oxford University Press, New York)

Romer, P, M, 1986, Increasing Returns and Long-Run Growth, Journal of Political Econo y 94, 1002-1037. 1989, Capital Accumulation in the Theory of Long-Run Growth, In R. Barro, ed., Modern Business Cycle Theory (Harvard University, Cambridge MA)

Sachs, J. D, 1987, Trade and exchange rate policies in growth-oriented adjustment programs, In V. Corbo, M. Goldstein, and M. Khan, eds., Growth-oriented Adjustment Programs (IMF and World Bank, Washington, D.C.)

Solow, R., 1956, A Contribution to the Theory of Economic Growth, Quarterly Journal of Economics 70, February 1956, 65-94.

Summers, R. and A. Heston, 1988, A New Set of International Comparisons of Real Product and Price Level Estimates for 130 Countries, 1950-85, Review of Income and Wealth 34, 1-25.

Young, A, 1991, Learaing by Doing and the Dynamic Effects of International Trade, Quarterly Journal of Economics 106, 369-406.

World Bank, 1987, World Development Report 1987, Oxford University Press. 1988, World Development Report 1988, Oxford University Press.

1989a, Sub-Saharan Africa: From Crisis to Sustainable Growth, Washington: the World Bank, 1989. 1989b, World Development Report 1989, Oxford University Press. 
Figure 1: Distortionary Tax Rates and Growth (Alternative Elasticities of Substitution in Production)

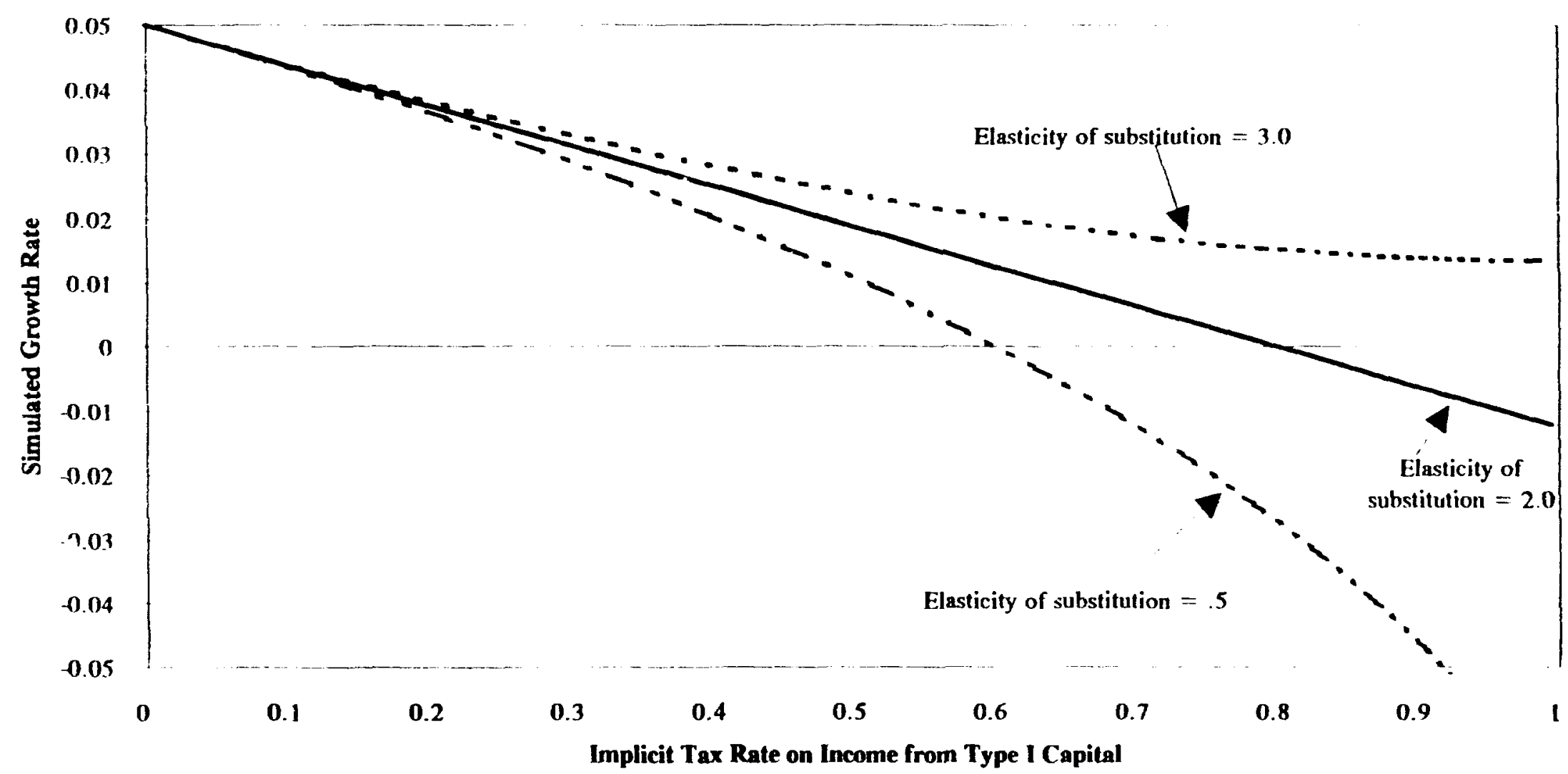


Figure 2: Welfare and distortion (Alternative elasticities of substitution in production)

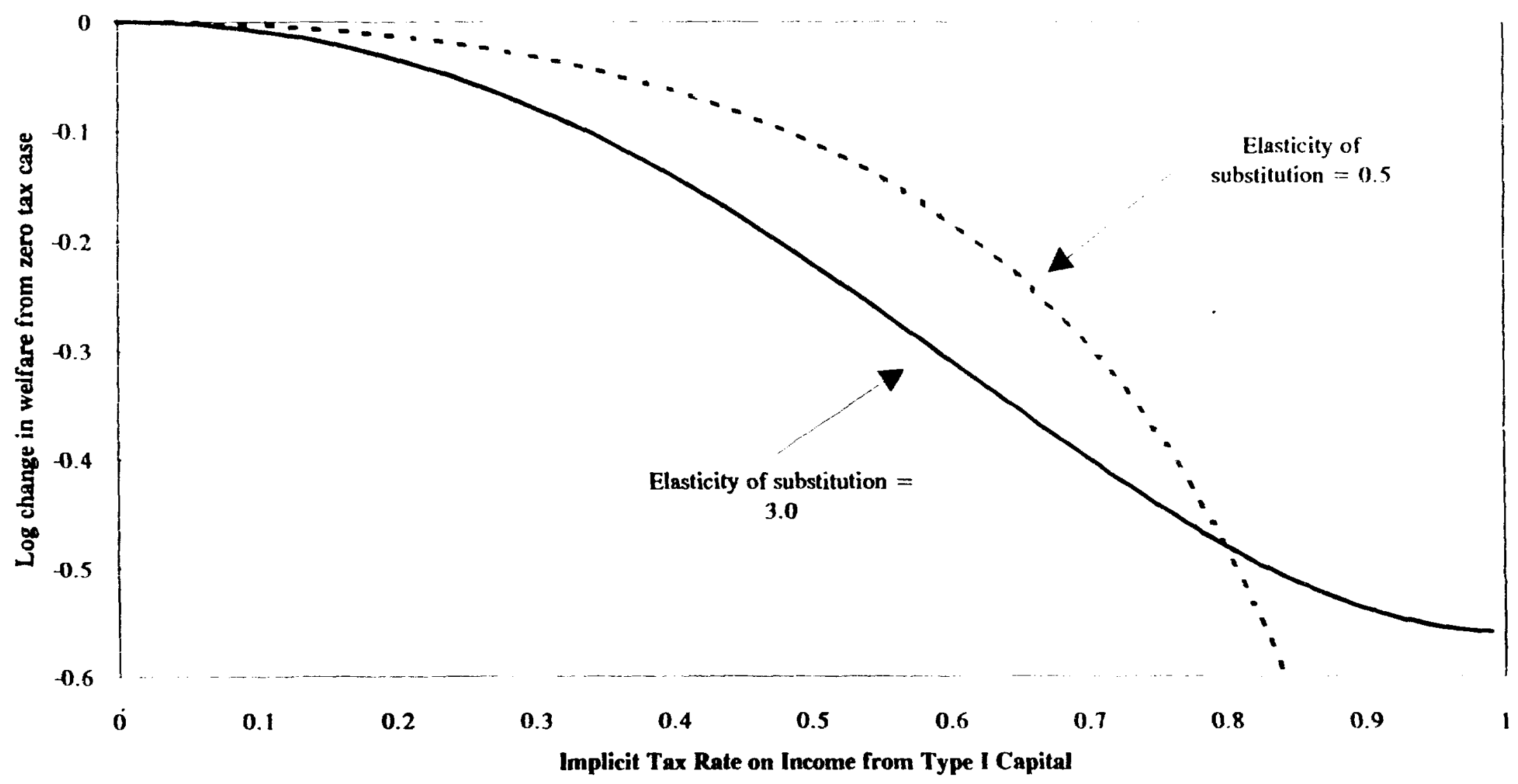




\begin{tabular}{|c|c|c|c|c|}
\hline & Title & Author & Date & $\begin{array}{l}\text { Contact } \\
\text { for paper }\end{array}$ \\
\hline WPS1194 & $\begin{array}{l}\text { How Fast Has Chinese Industry } \\
\text { Grown? }\end{array}$ & Tom Rawski & September 1993 & $\begin{array}{l}\text { E. Khine } \\
37471\end{array}$ \\
\hline WPS1195 & $\begin{array}{l}\text { The Enterprise Sector and } \\
\text { Emergence of the Polish Fiscal } \\
\text { Crisis, } 1990-91\end{array}$ & Mark Schatfer & September 1993 & $\begin{array}{l}\text { E. Khine } \\
37471\end{array}$ \\
\hline WPS1196 & $\begin{array}{l}\text { Corporate Tax Structure and } \\
\text { Production }\end{array}$ & $\begin{array}{l}\text { Joffrey Bernstein } \\
\text { Anwar Shian }\end{array}$ & September 1933 & $\begin{array}{l}\text { C. Jones } \\
37754\end{array}$ \\
\hline WPS1197 & $\begin{array}{l}\text { Determinants of Inflation among } \\
\text { Franc Zonie Countries in Africa }\end{array}$ & $\begin{array}{l}\text { Bruno Boccara } \\
\text { Shantayanan Devarajan }\end{array}$ & Seplember 1993 & $\begin{array}{l}\text { C. Jones } \\
37754\end{array}$ \\
\hline WPS1198 & $\begin{array}{l}\text { Enterprise Reform in China: The } \\
\text { Evolving Legal Framework }\end{array}$ & Natalie Lichtenstein & September 1993 & $\begin{array}{l}\text { M. Rangarajan } \\
81710\end{array}$ \\
\hline WPS1199 & $\begin{array}{l}\text { Public Pension Governance and } \\
\text { Performance: Lessons for Developing } \\
\text { Countries }\end{array}$ & Olivia Mitchell & October 1993 & $\begin{array}{l}\text { D. Evans } \\
37496\end{array}$ \\
\hline WPS1200 & $\begin{array}{l}\text { The Life-Cycle Distributional } \\
\text { Consequences of Pay-As-You-Go } \\
\text { and Funded Pension Systems }\end{array}$ & $\begin{array}{l}\text { Jane Falkinghiam } \\
\text { Paul Johnson }\end{array}$ & October 1993 & $\begin{array}{l}\text { D. Evans } \\
37496\end{array}$ \\
\hline WPS1201 & $\begin{array}{l}\text { Five Criteria for Choosing among } \\
\text { Poverty Programs }\end{array}$ & Margaret E. Grosh & October 1993 & $\begin{array}{l}\text { M. Quintero } \\
37792\end{array}$ \\
\hline WPS 1202 & $\begin{array}{l}\text { Privatization and Foreign Investment } \\
\text { in the Developing World, 1988-92 }\end{array}$ & Frank Sader & October 1993 & $\begin{array}{l}\text { Rose Vo } \\
33722\end{array}$ \\
\hline WPS1203 & $\begin{array}{l}\text { Determinants of Value-Added Tax } \\
\text { Revenue: A Cross-Section Analysis }\end{array}$ & $\begin{array}{l}\text { Zeljko Bogetic } \\
\text { Fareed Hassan }\end{array}$ & October 1993 & $\begin{array}{l}\text { F. Smith } \\
36072\end{array}$ \\
\hline WPS1204 & $\begin{array}{l}\text { Structural Adjustment, Economic } \\
\text { Performance, and Ais Dependency } \\
\text { in Tanzania }\end{array}$ & $\begin{array}{l}\text { Nisha Agrawal } \\
\text { Zatar Ammed } \\
\text { Michael Mered } \\
\text { Roger Nord }\end{array}$ & October 1993 & $\begin{array}{l}\text { K. Rivera } \\
34141\end{array}$ \\
\hline WPS1205 & $\begin{array}{l}\text { Wage and Employment Decisions } \\
\text { in the Russian Economy: An Analysis } \\
\text { of Developments in } 1992\end{array}$ & $\begin{array}{l}\text { Simon Commander } \\
\text { Leonid Liberman } \\
\text { Ruslan Yemtsov }\end{array}$ & October 1993 & $\begin{array}{l}\text { O. del Cid } \\
35195\end{array}$ \\
\hline WPS1206 & $\begin{array}{l}\text { Empirical Perspectives on National } \\
\text { Index Funds }\end{array}$ & $\begin{array}{l}\text { Isnac Diwan } \\
\text { Vinang Errunza } \\
\text { Lemma W. Senbet }\end{array}$ & October 1993 & $\begin{array}{l}\text { A. Yideru } \\
36067\end{array}$ \\
\hline WPS 1207 & $\begin{array}{l}\text { Characteristics and Petormance } \\
\text { of Settlement Programs: A Review }\end{array}$ & $\begin{array}{l}\text { Bill H. Kinsey } \\
\text { Hans P. Binswanger }\end{array}$ & Octoder 1993 & $\begin{array}{l}\text { H. Binswanger } \\
31871\end{array}$ \\
\hline
\end{tabular}




\section{Pollcy Research Working Paper Serles}

\section{Title}

WPS1208 Primary School Achievement in English and Mathematics in Zimbabwe: A Multi-Level Analysis

WPS1209 Should East Asia Go Regional? No, No, and Maybe

WPS1210 The Taxation of Natural Resources: Principles and Policy Issues

WPS1211 Savings-Investment Correlations and Capital Mobility in Developing Countries

WPS1212 The Links between Economic Policy and Research: Three Examples from Ghana and Some Gerieral Thoughts

WPS1213 Japanese Foreign Direct Investment: Kwang W. Jun Recent Trends, Determinants, and Prospects

WPS1214 Trade, Aid, and Investment in Sub. Saharan Africa

WPS1215 How Much Do Distortions Affect Growth?

WPS1216 Regulation, Institutions, and Commitment: Privatization and Regulation in the Argentine Telecommunications Sector

WPS1217 Unitary versus Collective Models of the Household: Time to Shift the Burden of Proot?
Author

Levi M. Nyagura

Abby Riddell

Arvind Panagariya

Robin Boadway

Frank Flatters

Nlandu Mamingi

Ravi Kanbur Frank Sader Haruo Horaguchi Hyuntai Kwak

Ishrat Husain

William Easterly

Alice Hill

Manuel Angel Abdala

Pierre-Andre Chiappori

Lawrence Haddad John Hoddinott

Ravi Kanbur

\section{Date}

October 1993

Contact for paper

1. Conachy 33669

October 1993

D. Ballantyne 37947

October 1993

C. Jones 37699

October 1993

R. Vo 31047

October 1993

P. Attipoe 526.3003

November 1993

S. King-Watson 33730

November 1993

M. Youssef 34637

November 1993

R. Martin 39065

November 1993

D. Evans 38526

November 1993

P. Attipoe 526-3002 